\title{
Evaluasi Pemberantasan Demam Berdarah Dengue dengan Metode Spasial Geographic Information System (GIS) dan Identifikasi Tipe Virus Dengue di Kota Kediri
}

\section{Evaluation of Dengue Hemorrhagic Fever Eradication with Geographic Information System (GIS) Spatial Method and Dengue Virus Type Identification in Kediri}

\author{
Yuly Peristiowati ${ }^{1}$, Lingga ${ }^{1}$, Hariyono ${ }^{2}$ \\ ${ }^{1}$ Sekolah Tinggi Ilmu Kesehatan Surya Mitra Husada Kediri \\ ${ }^{2}$ Kantor Lingkungan Hidup Kota Kediri
}

\begin{abstract}
ABSTRAK
Penyakit demam berdarah dengue (DBD) merupakan salah satu masalah kesehatan masyarakat di Indonesia dan sering menimbulkan suatu kejadian luar biasa (KLB). Salah satu yang bisa dilakukan untuk merancang program pemberantasan dan pencegahan DBD yang lebih baik adalah dengan melakukan analisis spasial dengan menggunakan Geographic Informatioon System (GIS). GIS dapat memetakan penyakit berbasis alamat penderita bermanfaat dalam melihat sebaran penyakit sehingga mampu mengidentifikasi daerah yang berisiko tinggi. Selain itu, dilakukannya analisis spasial memungkinkan suatu penyakit untuk dilihat dari berbagai konteks sehingga diharapkan mampu dilakukan perencanaan yang lebih baik dalam memberantas dan mencegah suatu penyakit. Hasil penelitian ini menunjukkan ada pengaruh faktor keberadaan kontainer air, sanitasi lingkungan dan kepadatan vektor terhadap peningkatan kasus DBD di Kota Kediri. Perilaku masyarakat berpengaruh dalam upaya pencegahan dan pemberantasan DBD terhadap terhadap kejadian penyakit DBD di Kota Kediri. Hasil identifikasi tipe virus DHF dengan menggunakan PCR di daerah endemis DBD kota Kediri di dapatkan serotype negative untuk Den-1, Den-2, Den-3 dan Den-4. GIS berperan dalam evaluasi program pemberantasan kasus DBD di Kota Kediri dimana dapat menggambarkan peta daerah kasus endemis DBD di kota Kediri.
\end{abstract}

Kata Kunci: Demam berdarah, Geographic Informatioon System (GIS), tipe virus dengue

\begin{abstract}
Dengue hemorrhagic fever is one of the public health problems in Indonesia and often leads to an extraordinary occurrence. Performing spatial analysis using Geographic Information System (GIS) can be used to design an eradicating program and better dengue prevention. GIS can map diseases based on sufferers' addresses and is useful in looking at the distribution of the disease as to identify high risk areas. Besides, spatial analysis allows a disease to be viewed from a variety of contexts that are expected to do better planning in combating and preventing a disease. The results show there are correlations between the presence of water containers, environmental sanitation, and vector densities to the increasing dengue cases in Kediri. People's behavior influences the prevention and eradication of the incidence of DHF in Kediri. The identification results of DHF virus type using PCR in dengue endemic areas in Kediri show negative serotype for Den-1, Den-2, Den-3 and Den-4. GIS that plays a role in the evaluation of dengue fever cases eradication program in Kediri can draw a map of the area of endemic dengue cases in Kediri.
\end{abstract}

Keywords: Dengue fever, dengue virus type, Information Geographic Systems (GIS)

Jurnal Kedokteran Brawijaya, Vol. 28, No. 2, Agustus 2014; Korespondensi: Yuly Peristiowati. Sekolah Tinggi Ilmu Kesehatan Surya Mitra Husada Kediri, Jl. Manila, No.37, Sumberece Kediri Tel. (0354)7009713 Email:yulystikes@gmail.com 


\section{PENDAHULUAN}

Penyakit demam berdarah dengue (DBD) merupakan salah satu masalah kesehatan di Indonesia dan sering menimbulkan kejadian luar biasa (KLB). Pada tahun 2008 tercatat ada 136.399 kasus Demam Berdarah, sekitar 1.170 korban di antaranya meninggal dunia. Umumnya, kasus ini terjadi pada anak-anak. Sepanjang tahun 2009 jumlah kasus naik menjadi 154.855 kasus dan 1.384 meninggal dunia (1).

Kasus DBD menunjukkan kecenderungan peningkatan jumlah kasus dan luas daerah terjangkit. Seluruh wilayah Indonesia mempunyai risiko untuk terjangkit penyakit $\mathrm{DBD}$, kecuali daerah yang memiliki ketinggian lebih dari 1.000 meter diatas permukaan (2)

Kota Kediri terdiri dari 3 Kecamatan yaitu Kecamatan Mojoroto, Pesantren, dan Kecamatan Kota, dan semuanya merupakan daerah endemis DBD. Dari data Dinas kesehatan Kota Kediri jumlah kasus DBD mengalami peningkatan dari tahun ketahun. Pada tahun 2011 didapatkan sebanyak 67 kasus, dengan kasus tertinggi di kecamatan Mojoroto sebanyak 29 kasus. Pada tahun 2012 didapatkan kasus DBD sebanyak 105 dan kasus tertinggi masing di kecamatan Mojoroto sebanyak 33 kasus. Pada awal tahun 2013 sampai bulan Agustus didapatkan sejumlah 260 kasus DBD dengan daerah endemis tertinggi di kecamatan kota sejumlah 102 kasus (3)

Berdasarkan data dari Badan Pusat Statistik Kota Kediri Tahun 2010, persentase cakupan rumah sehat 75\%, cakupan air bersih $79 \%$ dan cakupan pengelolaan sampah $52,7 \%$. Sumber air bersih masyarakat pada umumnya diperoleh dari Perusahaan Daerah Air Minum (PDAM) untuk masyarakat di kota dan sumur gali untuk masyarakat di pinggiran kota. Masyarakat yang menggunakan sumur gali masih mempunyai kebiasaan untuk menyimpan/menampung air bersih dalam ember, gentong air, drum-drum maupun bak-bak penampungan air lainnya, sehingga dapat berpotensi sebagai tempat perkembangbiakan nyamuk vektor DBD (4).

Kegiatan penanggulangan yang biasa dilakukan oleh Dinas Kesehatan Kota/Kabupaten adalah penyuluhan, fogging fokus, fogging masal, program ikanisasi, yaitu pemberian ikan pemakan jentik pada semua rumah tangga yang ada, dan juga pembagian brosur yang berisi mengenai pencegahan, dan penanggulangan demam berdarah dan gerakan $3 \mathrm{M}$ (menguras, menutup dan mengubur). Kegiatan pemberantasan sarang nyamuk demam berdarah dengue (PSN-DBD) sampai saat ini belum optimal, terbukti masih tingginya kasus DBD di Indonesia. Tingginya tingkat pengetahuan masyarakat mengenai pencegahan DBD akan mempengaruhi sikap untuk mengambil keputusan dalam berperilaku. Sikap seseorang dalam upaya mencegah penyakit DBD merupakan hal yang sangat penting karena setelah seseorang memiliki pengetahuan dan pengalaman mengenai penyakit DBD, maka dia akan memiliki keyakinan dan melakukan upaya tindakan $(5,6)$

Salah satu cara yang bisa dilakukan dalam merancang program pemberantasan dan pencegahan DBD yang lebih baik adalah dengan melakukan analisis spasial dengan menggunakan Geographic Informatioon System (GIS). GIS merupakan suatu sistem informasi yang mengelola data yang memiliki informasi spasial bereferensi keruangan. Kemampuan GIS untuk memetakan penyakit berbasis alamat penderita bermanfaat dalam melihat sebaran penyakit sehingga mampu mengidentifikasi daerah yang berisiko tinggi. Selain itu, dilakukannya analisis spasial memungkinkan suatu penyakit untuk dilihat dari berbagai konteks sehingga diharapkan mampu dilakukan perencanaan yang lebih baik dalam memberantas dan mencegah suatu penyakit (7)

Kajian ini diharapkan mampu mendapatkan gambaran spasial kasus DBD, mengidentifikasi faktor risiko perilaku, demografi, dan geografi terhadap penyebaran DBD sehingga dapat memberi petunjuk intervensi kesehatan masyarakat yang efektif yang dapat diterapkan dalam tindakan pencegahan dan pemberantasan penyakit DBD. Dengan adanya pendekatan ini diharapkan angka kejadian kasus DBD di kota Kediri bisa menurun dan tidak menjadi daerah endemis.

\section{METODE}

Rancangan penelitian ini menggunakan desain deskriptif kualitatif dengan pendekatan studi kasus (case study). Untuk mengetahui faktor yang mempengaruhi pemberantasan DBD di kota kediri di gunakan desain kuantitatif observasional dengan pendekatan cross sectional (8-10)

Tahapan penelitian yang dilakukan adalah mengumpulkan data dari Dinas Kesehatan terkait jumlah kasus Demam Berdarah Dengue di kota Kediri sejak tahun 2011 s.d 2013, kemudian dilanjutkan pengumpulan data statistik mengenai kepadatan penduduk di kota Kediri dari Badan Pusat Statistik Kota Kediri, melakukan survei di daerah kasus DBD mengenai: nilai kepadatan nyamuk (Bruteu indeks), tempat-tempat penampungan air (Container index), rumah yang terdapat jentik nyamuk (House Index). Pada tahap selanjutnya untuk mengidentifikasi tipe virus dengue dilakukan pengambilan sampel darah pasien yang positif menderita di seluruh Rumah Sakit wilayah kota Kediri dan dilakukan pemeriksaan PCR.

Data yang telah diperoleh, kemudian dianalisa untuk mengetahui penyebaran kasus DBD di kota Kediri berdasarkan data spasial GIS dan kondisi lingkungan daerah endemis DBD, sedangkan untuk mengetahui keterkaitan faktor penyebab peningkatan kasus DBD di kota Kediri dilakukan uji statistic Chi-Square dengan $\alpha=$ 0,05 (8-10).

\section{HASIL}

Hasil penelitian pada Tempat Penampungan Air (TPA) menunjukkan, di antara 611 TPA yang diperiksa, sebanyak 76 (12,4\%) TPA positif larva, dan 14 (2,3\%) TPA positif pupa. Bak mandi/WC (in door) merupakan TPA yang paling banyak ditemukan larva sebanyak 28 (11,2\%) dari 249 bak mandi/wc (in door) yang diperiksa. Dari 35 pot bunga yang di periksa, paling banyak ditemukan pupa sebanyak $5(35,7 \%)$ dan ditemukan larva sebanyak 6 $(9,8 \%)$.

Tabel 1. Jenis tempat penampungan air yang positif larva/pupa

\begin{tabular}{llrrr}
\hline No & Jenis TPA & Jumlah (\%) & $\begin{array}{r}\text { Jumlah } \\
\text { TPA (+) } \\
\text { Larva (\%) }\end{array}$ & $\begin{array}{r}\text { Jumlah } \\
\text { TPA (+) } \\
\text { Pupa (\%) }\end{array}$ \\
\hline 1. & Bak mandi/WC (in door & $249(40,7 \%)$ & $28(11,2 \%)$ & $0(0 \%)$ \\
2. & Bak mandi/WC (out door & $104(17 \%)$ & $12(19,6 \%)$ & $1(7,1 \%)$ \\
3. & Bak (penampung air) & $108(17,6 \%)$ & $5(8,2 \%)$ & $2(14,2 \%)$ \\
4. & Padasan & $36(5,9 \%)$ & $3(4,9 \%)$ & $1(7,1 \%)$ \\
\hline
\end{tabular}


Tabel 1. Jenis tempat penampungan air yang positif larva/pupa (Lanjutan)

\begin{tabular}{|c|c|c|c|c|}
\hline No & Jenis TPA & Jumlah (\%) & $\begin{array}{c}\text { Jumlah } \\
\text { TPA (+) } \\
\text { Larva (\%) }\end{array}$ & $\begin{array}{c}\text { Jumlah } \\
\text { TPA (+) } \\
\text { Pupa (\%) }\end{array}$ \\
\hline 5. & Pot bunga & $37(6 \%)$ & $6(9,8 \%)$ & $5(35,7 \%)$ \\
\hline 6. & Tempat minum burung & $27(4,4 \%)$ & $2(3,2 \%)$ & $1(7,1 \%)$ \\
\hline 7. & Ban bekas & $4(0,6 \%)$ & $3(4,9 \%)$ & $3(21,4 \%)$ \\
\hline 8. & Botol bekas & $10(1,6 \%)$ & $0(0 \%)$ & $0(0 \%)$ \\
\hline 9. & Kaleng bekas & $8(1,3 \%)$ & $1(1,6 \%)$ & $0(0 \%)$ \\
\hline \multirow[t]{2}{*}{10.} & Ember bekas & $29(4,7 \%)$ & $1(1,6 \%)$ & $1(7,1 \%)$ \\
\hline & TOTAL & $611(100 \%)$ & $76(12,4 \%)$ & $14(2,3 \%)$ \\
\hline
\end{tabular}

Keberadaan kontainer air diukur menggunakan indikator Maya Index. Maya Index tinggi mengambarkan lingkungan yang ideal untuk tempat perkembangbiakan nyamukAedes. Pada penelitian ini menunjukkan dari 113 responden yang berada pada lingkungan dengan status Maya Index tinggi, 72 responden $(63,7 \%)$ berasal dari kelompok kasus (DBD tinggi), dan 41 responden 36,3\%) berasal dari kelompok kontrol (DBD rendah). Sebanyak 121 responden yang berada pada lingkungan dengan status Maya Index rendah, 6 responden (5,0\%) berasal dari kelompok kasus (DBD tinggi), dan 115 responden $(95,0 \%)$ berasal dari kelompok kontrol (DBD rendah). Uji Chi-square dengan $\alpha=0,05$ menunjukkan $p=0,000<0,05$ menunjukkan terdapat hubungan antara keberadaan kontainer dengan kejadian penyakit DBD, dengan OR=33,6 ( Cl 95\% =13,6-83,3).

Kepadatan vektor diukur dengan menggunukan Breteau index. Hasil penelitian menunjukkan pada daerah dengan breteau index tinggi didapatkan pula kasus DBD yang tinggi, seperti yang tertera pada Tabel 2.

Tabel 2. Distribusi responden menurut keberadaan kontainer air

\begin{tabular}{lccr}
\hline \multirow{2}{*}{$\begin{array}{l}\text { Kejadian } \\
\text { DBD }\end{array}$} & \multicolumn{2}{c}{ Maya Index (Keberadaan kontainer) } & \multirow{2}{*}{ Total } \\
\cline { 2 - 3 } & \multicolumn{2}{c}{ Rendah } & \multicolumn{2}{c}{ Tinggi } & \\
\hline Kasus & $6(5,0 \%)$ & $72(63,7 \%)$ & $78(33,3 \%)$ \\
Kontrol & $115(95,0 \%)$ & $41(36,3 \%)$ & $156(66,7 \%)$ \\
Total & $121(100 \%)$ & $113(100 \%)$ & $234(100 \%)$ \\
\hline
\end{tabular}

Hasil uji fisher's exact test dengan $\alpha=0,05$ menunjukkan $\mathrm{p}=0,006<0,05$, menunjukkan terdapat hubungan antara kepadatan vektor dengan kejadian penyakit DBD dengan $\mathrm{OR}=8,4(\mathrm{Cl} 95 \%=1,8-346,7)$.

Perilaku pemberantasan Sarang Nyamuk (PMN) diduga juga memiliki peran dalam kejadian angka kejadian DBD. Hasil penelitian di dapatkan di antara 123 responden yang tindakan PSN baik, sebanyak 20 (16,3\%), yang bertempat tinggal di daerah kasus DBD tinggi, dan yang bertempat tinggal di daerah kasus DBD rendah sebanyak $103(83,7 \%)$, sedangkan dari 111 responden yang tindakan PSN kurang, sebanyak $58(52,3 \%)$ yang bertempat tinggal di daerah kasus DBD tinggi, dan yang bertempat tinggal di daerah kasus DBD rendah sebanyak 53 (47,7\%). Hasil uji ChiSquare dengan $\alpha=0,05 p=0,000$ menunjukkan terdapat hubungan antara tindakan PSN dengan kejadian penyakit $\mathrm{DBD}$, dengan $\mathrm{OR}=5,6(\mathrm{Cl} 95 \%=3,1-10,3)$.
Pada penelitian ini dilakukan identifikasi tipe virus demam berdarah dengan menggunakan metode PCR. Pada pemeriksaan ini identifikasi tipe Virus DHF diambil dari darah penderita yang sudah secara klinis terdiagnosis DBD. Didapatkan 2 pasien DBD dari rumah sakit Gambiran Kediri dan RS Bhayangkara Kediri.

Pasien tersebut mengalami gejala penigkatan suhu tubuh, terdapat ptecie, dan mengalami penurunan kadar trombosis. Selanjutnya diambil sampel darah perifer sebayak $5 \mathrm{ml}$. Darah penderita DBD di lakukan pemeriksaan PCR di laboratorium Tropical Desease Center (TDC)

Pemeriksaan dengan menggunakan antibody Den-1, Den2, Den-3, dan Den-4. Primer yang di gunakan dalam penelitian ini mengacu pada susunan primer yang di publikasikan oleh Lanciotti. Ukuran pita yang diharapkan dari hasil amplifikasi untuk dengue tipe 1 adalah 486 basepair (bp), tipe dengue 2 adalah 119 bp, tipe 3 dengue adalah 290 bp dan tipe 4 dengue adalah 389 bp. Data yang diperoleh kemudian dianalisis deskriptif untuk menggambarkan distribusi serotipe virus dengue. Gambaran hasil PCR kedua responden dapat dilihat pada gambar dibawah ini.

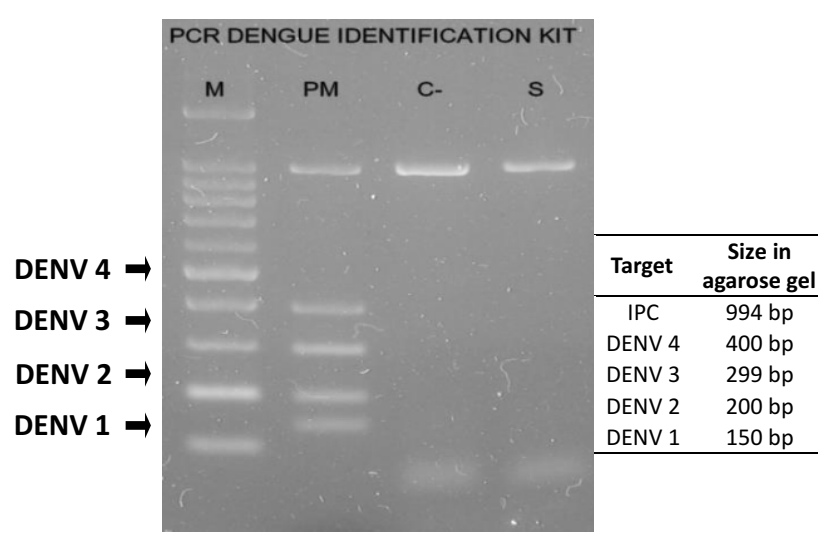

Gambar 1. Identifikasi tipe virus DHF den-1,den 2, den -3 dan den -4 di kota Kediri (responden I).

$\begin{array}{ll}\text { Keterangan: } \\ \text { M : marker } \\ \text { PM } & \text { : positif marker } \\ \text { C- } & \text { : kontrol negatif } \\ \text { S } & \text { : sampel DHF-1 }\end{array}$

Pada Gambar 2 hasil pemeriksaan PCR darah penderita DBD di kota Kediri yang dilakukan pada kedua responden menunjukkan hasil negatif. Meskipun gejala klinis menunjukkan positif gejala DBD yaitu peningkatan suhu tubuh, adanya ptecie dan penurunan kadar trombosit, namun setelah dilakukan pemeriksaan PRC tidak menunjukkan tipe virus dengue baik Den-1, Den-2, Den-3, atau Den-4.

Dari hasil analisa GIS dari 3 kecamatan yaitu kecamatan Pesantren, kecamatan Kota dan kecamatan Mojoroto terlihat penyebaran kasus yang hampir merata pada tiga kecamatan tersebut. Kasus tertinggi terdapat di kecamatan Kota sebanyak 260, kecamatan Pesantren sebanyak 95 kasus dan kecamatan Mojoroto sebanyak 63 kasus. 


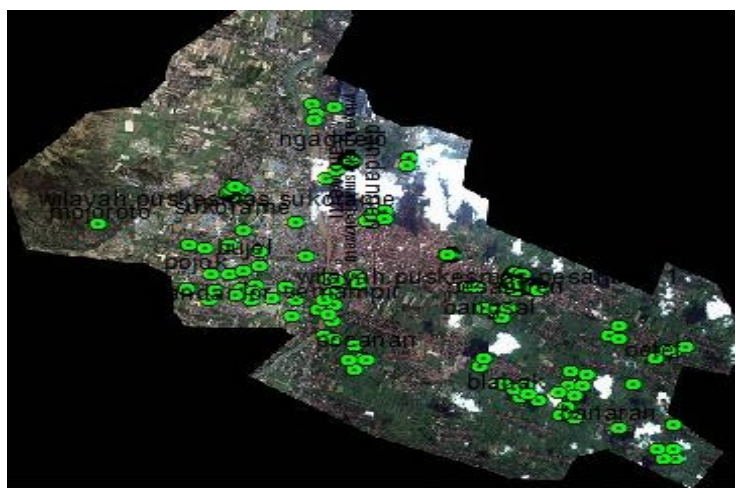

Gambar 3. Analisa spacial GIS kasus DBD kota Kediri tahun 2013

\section{DISKUSI}

Hasil penelitian menunjukkan keberadaan kontainer air mempengaruhi kejadian penyakit DBD di kota Kediri dengan nilai $p=0,000$ dengan $O R=28,4(\mathrm{Cl} 95 \%=12,1-$ $66,8)$. Artinya keberadaaan kontainer yang tinggi mempunyai risiko terhadap kejadian DBD sebanyak 28,4 kali lebih besar dibandingkan dengan keberadaan kontainer yang rendah.

Keberadaan kontainer sangat berperan dalam kepadatan vektor nyamuk Aedes, karena semakin banyak kontainer akan semakin banyak tempat perindukan perkembangbiakan nyamuk Aedes dan akan semakin padat populasi nyamuk Aedes. Semakin padat populasi nyamuk Aedes, maka semakin tinggi pula risiko terinfeksi virus DBD dengan waktu penyebaran lebih cepat sehingga jumlah kasus penyakit DBD cepat meningkat yang pada akhirnya mengakibatkan terjadinya kejadian luar biasa/KLB (2,11-13).

Berdasarkan penelitian sebelumnya yang dilakukan di sembilan wilayah perkotaan di Indonesia menunjukkan jentik nyamuk Ae.aegypti terdapat satu di antara tiga rumah tangga penduduk (13). Tempat perindukan perkembangbiakan nyamuk Ae.aegypti yang paling potensial terdapat pada penampungan air, bak air, tempayan dan drum-drum minyak tanah (14-16). Tempat yang paling banyak banyak ditemukan jentik yaitu bak mandi/WC (indoor) 35(51,5\%) bak, bak mandi/WC Out door $12(17,6 \%)$ bak, pot bunga $6(8,8 \%)$ buah, bak/tempat penampungan air $5(7,4 \%)$ buah, ban bekas $3(4,4 \%)$ buah, padasan $3(4,4 \%)$ buah, tempat minum burung $2(2,9)$ buah, kaleng bekas1 $(1,5 \%)$ buah, ember bekas $1(1,5 \%)$ buah, hasil penelitian ini hampir sama dengan hasil pada penelitian ini yaitu tempat perkembang biakan nyamuk aedes paling potensial pada bak mandi (indoor maupun outdoor dan bak penyimpanan air (1316).

Temuan ini menunjukkan program pemerintah berupa penyuluhan kesehatan masyarakat dalam penanggulangan penyakit DBD antara lain dengan cara menguras, menutup, dan mengubur (3M) sangat tepat, program tersebut perlu dukungan luas dari masyarakat dalam pelaksanaannya (17-20)

Kondisi sanitasi lingkungan berperan besar dalam perkembangbiakan nyamuk Aedes, terutama apabila terdapat banyak kontainer penampungan air hujan yang berserakan dan terlindung dari sinar matahari, apalagi berdekatan dengan rumah penduduk (21-22). Pengelolaan lingkungan berhubungan dengan angka kejadian DBD. Pada penelitian sebelumnya menunjukkan sebanyak responden dengan pengelolaan lingkungan yang kurang baik, 46,3\% menderita DBD, sedangkan pada responden dengan pengelolaan lingkungan yang baik, hanya 7,5\% yang menderita DBD (21).

Upaya yang harus dilakukan agar nyamuk tidak berkembang dan menyebarkan penyakit adalah memelihara kesehatan lingkungan. Memperbaiki sanitasi dan memelihara kesehatan lingkungan, bukan hanya menjadi beban dan tanggung jawab pemerintah, tetapi juga tanggung jawab seluruh komponen masyarakat $(21,22)$

Metode lingkungan untuk mengendalikan nyamuk antara lain dengan Pemberantasan Sarang Nyamuk (PSN), pengelolaan sampah padat, modifikasi tempat perkembangbiakan nyamuk hasil samping kegiatan manusia, dan perbaikan desain rumah. Sebagai contoh menguras bak mandi/penampungan air sekurangkurangnya sekali seminggu, mengganti/menguras vas bunga dan tempat minum burung seminggu sekali. menutup dengan rapat tempat penampungan air, mengubur kaleng-kaleng bekas, aki bekas dan ban bekas di sekitar rumah dan lain sebagainya $(23,24)$.

Kepadatan vektor nyamuk Aedes yang diukur dengan parameter angka Breteau Index (BI) yang diperoleh dari hasil penelitian dari 18 lingkungan (RW) di Kota Kediri, menunjukkan dari 7 lingkungan dengan Breteau Index (BI) tinggi ada 5 lingkungan di daerah kasus DBD tinggi (kasus), sedangkan dari 11 lingkungan dengan Breteau Index (BI) rendah ada 10 lingkungan di daerah kasus DBD rendah. Hal ini sesuai dengan hasil penelitian yang dilakukan oleh para peneliti sebelumnya yang menyatakan bahwa semakin tinggi angka kepadatan vektor akan meningkatkan risiko penularan penyakit DBD $(13,25-27)$.

Pada penelitian ini menunjukkan terdapat hubungan perilaku pemberantasan DBD dengan angka kejadian penyakit $D B D(O R=5,6)(C l 95 \%=3,1-10,3)$. Hasil yang didapat ini sesuai dengan beberapa penelitian sebelumnya yang menunjukkan bahwa tidakan ' $3 \mathrm{M}$ ' merupakan cara paling tepat dalam pencegahan dan penanggulangan terjadinya KLB penyakit DBD. Pemberantasan jentik nyamuk Aedes dengan penaburan butiran Temephos dengan dosis 1 ppm dengan efek residu selama 3 bulan cukup efektif menurunkan kepadatan populasi nyamuk Aedes atau meningkatkan angka bebas jentik, sehingga menurunkan risiko terjadinya KLB penyakit DBD $(20,28$ 31).

Meningkatnya jumlah kasus serta bertambahnya wilayah yang terjangkit, disebabkan karena semakin baiknya sarana transportasi penduduk, adanya pemukiman baru, kurangnya perilaku masyarakat terhadap pembersihan sarang nyamuk, terdapatnya vektor nyamuk hampir di seluruh pelosok tanah air serta adanya empat sel tipe virus yang bersirkulasi sepanjang tahun (30-31).

Dari hasil pemeriksaan PCR dengan menggunakan anti bodi Den-1,Den-2, Den-3 dan Den-4 yang dilakukan di laboratorium Tropical Desease Center (TDC) Universitas Airlangga Surabaya, pada 2 responden yang secara klinis sudah ada tanda dan gejala DBD yaitu peningkatan suhu tubuh, adanya ptechie dan penurunan kadar trombosit, namun secara pemeriksaan identifikasi tipe virus dengue 
menunjukkan hasil yang negatif. Pada ke dua responden tersebut belum dilakukan pemeriksaan laboratori untuk deteksi Ig $\mathrm{G}$ dan Ig $\mathrm{M}$ sehingga belum diketahui adanya infeksi dengue sekunder akut pada ke dua responden tersebut. Seharusnya sebelum dilakukan identifikasi tipe virus dengue dengan menggunakan PCR, serum penderita perlu dilakukan pemeriksaan IgG antidengue bersifat diagnostik, yang dapat menjadi parameter terjadinya dugaan infeksi dengue sekunder akut. Hal ini sesuai dengan teori heterologous infection maupun $A D E$ (Antibody Dependent Enhancement). Jadi IgG yang terdeteksi dalam pemeriksaan laboratorium tidak menunjukkan adanya proteksi atau sekedar infeksi virus dengue di masa lampau. Diagnosis yang telah ditegakkan dengan pemeriksaan klinis dan laboratoris, ditunjang

\section{DAFTAR PUSTAKA}

1. World Health Organization. Prevention Control of Dengue and Dengue Haemorrhagic Fever. Geneva: WHO; 1997.

2. Fathi, Keman S, dan Wahyuni CU. Peran Faktor Lingkungan dan Perilaku. Jurnal Kesehatan Lingkungan. 2005: 2(1): 1-10.

3. Dinas Kesehatan. Rekapitulasi Data Penderita Demam Berdarah Kota Kediri. Kediri: Dinkes; 2013.

4. Badan Pusat Statistik. Hasil Survei Sosial Ekonomi Nasional Tahun 2006 Propinsi Jawa Timur. (Online) 2006. http://jatim.bps.go.id/?hal=publikasi

5. Departemen Kesehatan Republik Indonesia. Petunjuk Teknis Pemberantasan Nyamuk Penular Demam Berdarah Dengue. Jakarta: Departemen Kesehatan RI: Jakarta; 1992.

6. Darmawansyah DSN dan Arsin AA. Analisis Faktor yang berhubungan Dengan Kejadian Demam Berdarah Dengue di Kecamatan Baruga Kota Kendari. [Tesis]. Universitas Hasanudin, Makasar. 2007.

7. Lasut D, Ruliansyah A, Darwin E, dan Ridwan W. Karakteristik dan Pergerakan Sebaran Penderita DBD Berdasarkan Geographic Information System sebagai Bagian Sistem Informasi Surveilans di Kecamatan Karawang Barat Kabupaten Karawang Provinsi Jawa Barat. Jurnal Penelitian Penyakit Tular Vektor. 2009; 1(1): 41-45.

8. Hastono PS. Metodologi Research. Jilid 3. Yogyakarta: Andi Publisher; 2001.

9. Notoatmodjo S. Metodologi Penelitian Kesehatan. Jakarta: PT. Rineka Cipta; 2002.

10. Murti B dan Neutens JJ. Prinsip \& Metode Riset Epidemiologi. Yogyakarta: Gajah Mada University Press; 1997.

11. Arsin AA, Wahiduddin, dan Noor NN. Factor Related to Dengue Haemorhagic Fever (DHF) in Makasar City, Departemen of Epidemiology. [Repository]. Universitas Hasanudin, Makasar. 2006.

12. Priyanto A. Evaluasi Kegiatan PSN Melalui Indikator Ada Tidaknya Jentik di Desa Endemis dan Bebas DBD di Kabupaten Demak. [Skripsi]. Universitas Diponegoro, Semarang. 2000.

13. Suparmanto. Faktor-faktor yang Berhubungan dengan pemeriksaan serologis adanya baik IgM anti dengue ataupun IgG anti dengue yang idealnya diikuti kadarnya (apabila memungkinkan), hal ini akan mempertajam diagnosis $\operatorname{DBD}(23,32)$.

Penelitian yang dilakukan oleh Departemen Kesehatan tahun 2003-2005 menghasilkan identifikasi DEN2,3 dan 4 di Sumatera Utara, tapi tidak ada DEN 1. Sangat beragamnya pola distribusi virus dengue sangat mendukung untuk pengembangan pembuatan vaksin di wilayah tertentu. Meskipun di kota Kediri belum teridentifikasi tipe virus Dengue yang spesifik, peneliti terus akan mengembangkan penelitian untuk mengidentifikasi tipe virus dengue sebagai dasar rencana pembuatan kabdidat vaksin DBD di kota Kediri (33-35).

dengan Keberadaan Jentik Nyamuk Aedes. (Online) 2007.

14. Nurjazuli, Ginandjar P, Wardani DWSR, and Hanani Y. Hubungan Faktor Kesehatan Lingkungan dengan Tinggi Rendahnya House Index Jentik Aedes di Desa Endemis dan Desa Bebas DBD Kotamadia Semarang. [Tesis]. Universitas Diponegoro, Semarang. 1998.

15. Suwarja. Kondisi Sanitasi Lingkungan dan Vektor Dengue Demam Berdarah pada Kasus Penyakit DBD di Kecamatan Tikala Kota Manado. [Tesis]. Universitas Gadjah Mada, Yogyakarta. 2007.

16. Octaviana D. Faktor Risiko Penyakit Demam Berdarah Dengue di Kecamatan Purwodadi Kabupaten Grobogan Jawa Tengah. [Tesis]. Universitas Gadjah Mada, Yogyakarta. 2007.

17. Departemen Kesehatan Republik Indonesia. Petunjuk Teknis Pengamatan Penyakit Demam Berdarah Dengue. Jakarta: Departemen Kesehatan RI: 1992.

18. Langkap. Partisipasi Keluarga dalam Pencegahan Demam Berdarah Dengue di Kabupaten Kota Waringin Timur. Universitas Gadjah Mada, Yogyakarta. 2004.

19. Sutomo S. Rencana Strategi Pencegahan dan Pemberantasan Demam Dengue/Demam Berdarah Dengue 2004-2006. Jakarta: Depkes RI; 2003.

20. Suroso T. Strategi Baru Penanggulangan DBD di Indonesia. Jakarta: Depkes RI; 2003.

21. Tamawiwy WH, Pratiwi B, Tombi R, dan Tarmizi. Hubungan Sanitasi dan Demam Berdarah Dengue di $\mathrm{Man}$ ad o. ( $\quad(\mathrm{n} \mathrm{I} \mathrm{i} \mathrm{ne}) \quad 2006$. http://www.scribd.com/doc/72968102/HubunganSanitasi-Lingkungan-Dengan-Kejadian-DBD-DiDaerah-Pesis

22. Suyasa ING, Putra NA, dan Aryanta IWR. 2007. Hubungan Faktor Lingkungan dan Perilaku Masyarakat dengan Kebaradaaan Vektor DBD di Wilayah Kerja Puskesmas Denpasar. Ecotrophic. 2007; 3(1): 1-6.

23. Aryati. Diagnosis Laboratories DBD Terkini. Simposium Sehari "Penangan DBD Terkini" Fakultas Kedokteran Departemen Patologi Klinik. Surabaya, 2004.

24. Kusriastuti R. Kebijakan Penanggulangan Demam Berdarah Dengue di Indonesia. Simposium Nasional DBD. Pusat Studi Bioteknologi UGM Yogyakarta. Yogyakarta, 16 Mei 2007. 
25. Kusnanto H. Surveilans Demam Berdarah Dengue. Simposium National DBD. Pusat Studi Bioteknologi UGM Yogyakarta. Yogyakarta, 16 Mei 2007.

26. Sukowati S. Tinjauan Hasil Penelitian Vektor Penyakit di Indonesia. Lokakarya II Tinjauan Hasil Penelitian Ekologi Kesehatan. Badan Litbang Kesehatan 1/35. Jakarta, 1990.

27. Supartha IW. Pengendalian Terpadu Vektor Demam Berdarah Dengue, Aedes aegypti dan Aedes albipictus. Pertemuan IImiah. Bali, 3-6 September 2008.

28. Kasnodiharjo. Gambaran Perilaku Penduduk Mengenai Kesehatan Lingkungan di Daerah Pedesaan Subang Jawa Barat. Pusat Penelitian Ekologi Kesehatan. Jakarta: Puslitbang PT Kalbe Farma; 1997.

29. Hadinegoro SR dan Satari HI. 2002. Demam Berdarah Dengue, Naskah Lengkap Pelatihan Bagi Pelatih Dokter Spesialis Anak dan Dokter Spesialis Penyakit Dalam, dalam Tata Laksana Kasus DBD. Jakarta: Balai Penerbit FKUI; 2002.

30. Sarwono S. Pengantar Ilmu Perilaku Kesehatan. Jakarta: Balai Penerbit FKUI; 1997.
31. Notoadmojo S. Pendidikan dan Perilaku Kesehatan. Jakarta: PT Rineka Cipta; 2003.

32. Ginting AP, Soegijanto S, dan Darmowandowo W. Pola Serotype Virus Dengue di Indonesia sebagai Awal Persiapan Pembuatan Vaksin Dengue di Indonesia. [Riset]. Universitas Airlangga, Surabaya. 2009.

33. Tambunan R. Deteksi dan Penentuan Virus Dengue Serotype 1 dari Serum Penderita Demam Berdarah Dengue di Rumah Sakit Kota Medan Menggunakan Reverse Transcriptase Polymerase Shain Reaction (PCR). [Tesis]. Universitas Sumatera Utara, Medan. 2009

34. Tedjo S, Benekdiktus Y, Tri Yuli S, Aryati, Puspa W, dan Fedik A. Identifikasi Genotip dan Karakteristik Genome Virus Dengue di Indonesia untuk Penentuan Prototype Virus Bahan Pembuatan Vaksin Dengue Berbasis Strain Indonesia. Prosiding InSINas. 2012; hal. 1-5.

35. Suwanwong $Y$, Moungkote $T$, Wiwanikit $V$, and Soogarun S. Detection of Dengue Virus by Simple RTPCR using Universal Degenerate Primers Observation from Apreliminary Study. Archives of Hellenic Medicine. 2010; 27(5): 818-821. 